\title{
Aflatoxin and Kojic Acid Production by Resting Cells of Aspergillus flavus Link
}

\author{
By S. C. BASAPPA, V. SREENIVASAMURTHY AND H. A. B. PARPIA \\ Central Food Technological Research Institute, Mysore, India
}

(Accepted for publication 15 December 1969)

\begin{abstract}
SUMMAR Y
Resting Aspergillus flavus synthesized more aflatoxin on a medium with glucose than they did with any other substrate tested. D-Xylose and ethanol fostered the formation of kojic acid but not aflatoxin. Yields of kojic acid and aflatoxin responded differently to alteration in temperature, $\mathrm{pH}$, surface-volume ratio of the culture medium, and the presence of various chemicals in the medium. $\left[{ }^{14} \mathrm{C}\right]$ Acetate as a substrate led to strongly labelled aflatoxin being formed. The simultaneous addition of unlabelled kojic acid did not lower the relative isotope content of the synthesized toxin. On the other hand, addition of unlabelled acetate to medium with $\left[{ }^{14} \mathrm{C}\right] \mathrm{kojic}$ acid did reduce the relative isotope content of the toxin synthesized. It is concluded that the synthesis of kojic acid and aflatoxin follow separate pathways, and that kojic acid is not an intermediate in aflatoxin synthesis by resting cells of $A$. flavus.
\end{abstract}

\section{INTRODUCTION}

Amongst the toxic metabolites of Aspergillus flavus, kojic acid has been known for several decades, and aflatoxin since 196r. The observations of Davis (1963), that an aflatoxin-forming strain of $A$. flavus produced kojic acid suggested a biosynthetic relationship between the two compounds. This is further supported by the fact that the bisdihydrofuran moiety is seen in aflatoxin as well as in sterigmatocystin in whose biosynthesis kojic acid has a key position. This lead Holker \& Underwood (I964) and Heathcote, Child \& Dutton (1965) to postulate that aflatoxin might be derived biogenetically from a compound similar in structure to sterigmatocystin. Parrish Wiley, Simmons \& Long (I966) found that all aflatoxin-forming strains of A. flavus produced kojic acid but not all kojic acid-forming strains produced aflatoxin. This close association of kojic acid with aflatoxin in toxin-forming strains of $A$. flavus posed the question whether kojic acid formation is an intermediate step in toxin biosynthesis. This point has been examined with the use of resting A. flavus.

\section{METHODS}

The organism. An isolate obtained from infected groundnuts and identified as Aspergillus flavus was used. It was preserved in sterile soil and stored at $5^{\circ}$.

Inoculum. A loopful of the soil was transferred to Czapek-Dox agar slant and incubated at $25^{\circ}$ for 5 days. Heavy mycelial growth and sporulation were obtained. The conidia formed were suspended in sterile distillation water and used as the inoculum.

Preparation of resting organisms. Czapek-Dox-Casein-thiamine medium (Basappa, 
Jayaraman, Sreenivasamurthy \& Parpia, 1967) inoculated with the conidia was incubated without agitation at $25^{\circ}$ for $48 \mathrm{hr}$. The mycelium was washed with cold sterile distilled water and finally with cold, sterile, resting-mycelium medium. The composition of this was as described by Adye \& Mateles (1964) but without glucose. The washed mycelium, in four times its weight of resting mycelium medium was blended in a Waring Blender for $30 \mathrm{sec}$. Twenty $\mathrm{ml}$. of this was placed in each $100 \mathrm{ml}$. Erlenmeyer conical flask for experimental treatment. In experiments where ${ }^{14} \mathrm{C}$-compounds were used, $5 \mathrm{ml}$. was placed in a $50 \mathrm{ml}$. flask.

Substrates, inhibitors and stimulants. Concentrated solutions of substrates, inhibitors and stimulants were sterilized at $10 \mathrm{lb}$./in. pressure for $20 \mathrm{~min}$. and dispensed into flasks prior to the addition of resting cells. $\left[{ }^{14} \mathrm{C}\right] \mathrm{Kojic}$ acid was prepared biosynthetically by the resting cells of Aspergillus flavus using $\left[\mathrm{I}^{14} \mathrm{C}\right]$ acetate as carbon source. It was separated and purified on thin layer chromatoplates by the method described below.

Incubation. Preliminary studies showed that toxin began to form after $36 \mathrm{hr}$ incubation and reached its maximum at $72 \mathrm{hr}$. Resting mycelia were therefore incubated always for a period of $72 \mathrm{hr}$ at $25^{\circ}$. The $\mathrm{pH}$ of the medium, unless otherwise stated, was at 6.0 before incubation. All treatments were in triplicate and all results were confirmed by repeating at least once. The means of triplicated data from one experiment are reported.

Estimation of aflatoxin. After $72 \mathrm{hr}$ incubation the medium with the resting cells was repeatedly extracted with chloroform. Pooled extracts were cleaned by a procedure outlined by Mayura \& Sreenivasamurthy (1969) and concentrated. Concentrated extract was streaked on a number of thin-layer chromatoplates coated with silica gel $\mathrm{G}$. The plates were developed with chloroform containing $10 \%$ ethanol. The fluorescent band corresponding to aflatoxin B was scraped off and the toxin eluted with methanol. The clear methanol solution was heated in a water bath under reduced pressure to remove the solvent. The residue was dissolved in $5 \mathrm{ml}$. methanol and its absorption at $363 \mu \mathrm{m}$. in a D.U. spectrophotometer determined. Toxin concentration was obtained by watching the optical density against a standard curve.

Estimation of kojic acid. Kojic acid was estimated by the colorimetric method described by Bentley (I957) with ferric chloride as the reagent.

Isolation and purification of $\left[{ }^{14} \mathrm{C}\right]$ aflatoxin. Aflatoxin was extracted, purified and dissolved in methanol as described above. Eluate was transferred to a planchet and heated under infrared light to evaporate the solvent. Radioactivity counts were then determined using a windowless gasflow counter (Tracer Lab. U.S.A.).

Isolation and purification of $\left[{ }^{14} \mathrm{C}\right]$ kojic acid. The aqueous phase remaining after chloroform extraction was streaked on a thin layer chromatoplate. A small quantity of kojic acid was spotted at one end of the streak to serve as the reference spot. The plates were developed first with $10 \%$ ethanol in chloroform to separate any residual toxin, then with $4+\mathrm{I}+\mathrm{I}$ mixture of butanol + acetate acid + water to separate kojic acid. The kojic-acid band corresponding to the reference spot, which was detected by coloration with ferric chloride, was scraped off, eluted with water, and concentrated in a nitrogen atmosphere. A sample of the concentrate was evaporated on a planchet and its radioactivity count determined with a windowless gasflow counter. $\left[1-{ }^{14} \mathrm{C}\right]$ Acetate was obtained from Babha Atomic Research Centre, Trombay, Bombay, India. 


\section{RESULTS}

The yields of aflatoxin and kojic acid by Aspergillus flavus grown with different carbon sources are presented in Table I. On an equimolar basis glucose yielded more toxin than any other substrate. Sodium acetate was next best. Kojic acid yielded little toxin. D-Xylose and ethanol supported the formation of kojic acid, but yielded little toxin. The effects of altered temperature, $\mathrm{pH}$ and ratio of surface area/volume on synthesis of aflatoxin and kojic acid by resting mycelium are presented in Tables 2 , 3 and 4. Kojic acid synthesis with acetate as the substrate was maximal at $\mathrm{pH} 6 \cdot 0$ and 7.0 while aflatoxin yields were highest at $\mathrm{pH} 5^{\circ} 0$ and 6.0 . Similarly, kojic acid yield was highest at $37^{\circ}$ while aflatoxin yield was highest at $25^{\circ}$. Alteration in the ratio of surface area to volume markedly affected synthesis of aflatoxin but not of kojic acid.

Table I. Yields of aflatoxin and kojic acid by resting Aspergillus flavus in media with different carbon substrates

$\begin{array}{lcc}\begin{array}{c}\text { Substrate } \\ \text { 100 } \mu \text { mole } / \mathrm{ml} .\end{array} & \begin{array}{c}\text { Kojic acid } \\ (\mu \mathrm{g} . / \mathrm{ml} .)\end{array} & \begin{array}{c}\text { Aflatoxin } \\ (\mu \mathrm{g} . / \mathrm{ml} .)\end{array} \\ \text { None } & 30 \cdot 0 & 2.5 \\ \text { Na acetate } & 80.0 & 21.0 \\ \text { D-Glucose } & 300.0 & 56.0 \\ \text { Kojic acid } & 550.0 & 12.0 \\ \text { D-Xylose } & 200 \cdot 0 & 10.0 \\ \text { Ethanol } & 160.0 & 2.5\end{array}$

Table 2. Effect of $p H$ on yields of aflatoxin and kojic acid by resting Aspergillus flavus

$\begin{array}{lccc}\text { Substrate roo } \mu \mathrm{mole} / \mathrm{ml} . & \mathrm{pH} & \begin{array}{c}\text { Kojic acid } \\ (\mu \mathrm{g} . / \mathrm{ml} .)\end{array} & \begin{array}{c}\text { Aflatoxin } \\ (\mu \mathrm{g} . / \mathrm{ml} .)\end{array} \\ \text { Control (no substrate) } & 5.0 & 5.0 & 0.1 \\ \text { Control (no substrate) } & 6.0 & 5.0 & 0.2 \\ \text { Acetate } & 4.0 & 0.0 & 0.3 \\ \text { Acetate } & 5.0 & 90.0 & 26.4 \\ \text { Acetate } & 6.0 & 100.0 & 26.6 \\ \text { Acetate } & 7.0 & 100.0 & 0.2 \\ \text { Acetate } & 8.0 & 44.0 & 0.1\end{array}$

Table 3. Effect of temperature on yields of kojic acid and aflatoxin by resting Aspergillus flavus

Substrate: $100 \mu \mathrm{mole} / \mathrm{ml}$. acetate

$\begin{array}{ccc}\text { Temperature } & \begin{array}{c}\text { Kojic acid } \\ (\mu \mathrm{g} . / \mathrm{ml} .)\end{array} & \begin{array}{c}\text { Aflatoxin } \\ (\mu \mathrm{g} . / \mathrm{ml} .)\end{array} \\ 20 & 0.0 & 1.0 \\ 25 & 80.0 & 29 \cdot 0 \\ 28 & 100 \cdot 0 & 6.5 \\ 37 & 130.0 & 0 . \mathrm{I}\end{array}$

The results in Table 5 show that $\mathrm{Na}_{2} \mathrm{~S}_{2} \mathrm{O}_{4}$ increased the yield of the toxin, but not of kojic acid. Malonate on the other hand reduced the yield of kojic acid, but not of toxin. Hydroxylamine reduced the yield of both. Under an atmosphere of nitrogen, 
however, kojic acid yield was significantly increased while yield of toxin was slightly reduced. When kojic acid was the substrate instead of acetate, none of these treatments influenced yield of toxin.

Table 4. The effect of changes in the ratio of surface area to volume on yields of kojic acid and aflatoxin by resting Aspergillus flavus

Substrate: $100 \mu \mathrm{mole} / \mathrm{ml}$. acetate $/ \mathrm{ml}$.

\begin{tabular}{|c|c|c|}
\hline $\begin{array}{l}\text { Volume of } \\
\text { medium in } \\
\text { roo ml. flask } \\
\text { (ml.) }\end{array}$ & $\begin{array}{c}\text { Kojic acid } \\
(\mu \mathrm{g} . / \mathrm{ml} .)\end{array}$ & $\begin{array}{l}\text { Aflatoxin } \\
\text { ( } \mu \mathrm{g} . / \mathrm{ml} .)\end{array}$ \\
\hline 10 & 150 & 39 \\
\hline 20 & 170 & 38 \\
\hline 30 & I 40 & I2 \\
\hline 40 & I30 & 6.0 \\
\hline
\end{tabular}

Table 5. Effect of inhibitors and stimulants on yields of aflatoxin and kojic acid by resting Aspergillus flavus

Inhibitor/stimulant $\quad \begin{gathered}\text { Kojic acid } \\ (\mu \mathrm{g} . / \mathrm{ml} .)\end{gathered} \quad \begin{gathered}\text { Aflatoxin } \\ (\mu \mathrm{g} . / \mathrm{ml} .)\end{gathered}$

Substrate: $100 \mu$ mole acetate $/ \mathrm{ml}$.

\begin{tabular}{|c|c|c|}
\hline $\begin{array}{l}\text { Control } \\
\text { + } \mathrm{Na}_{2} \mathrm{~S}_{2} \mathrm{O}_{4} \mathrm{I} \mathrm{mg} . / \mathrm{ml} . \\
\text { + Malonate } 5 \mathrm{mg} . / \mathrm{ml} . \\
\text { + Sulphanilamide } 0.5 \mathrm{mg} . / \mathrm{ml} \text {. } \\
\text { + Hydroxylamine O.I mg. } / \mathrm{ml} \text {. } \\
\text { + Under nitrogen }\end{array}$ & $\begin{array}{r}85 \cdot 0 \\
70 \cdot 0 \\
5 \cdot 0 \\
28 \cdot 0 \\
5 \cdot 0 \\
160 \cdot 0\end{array}$ & $\begin{array}{r}21 \cdot 0 \\
70 \cdot 0 \\
22 \cdot 0 \\
1 \cdot 0 \\
1 \cdot 0 \\
12 \cdot 0\end{array}$ \\
\hline \multicolumn{3}{|c|}{ Substrate: $50 \mu$ mole kojic acid $/ \mathrm{ml}$. } \\
\hline $\begin{array}{l}\text { Control } \\
\text { + } \mathrm{Na}_{2} \mathrm{~S}_{2} \mathrm{O}_{4} \mathrm{I} \mathrm{mg} . / \mathrm{ml} . \\
\text { + Sulphanilamide } 0.5 \mathrm{mg} . / \mathrm{ml} \text {. } \\
\text { + Hydroxylamine } \\
\text { + Malonate } 5.0 \mathrm{mg} . / \mathrm{ml} .\end{array}$ & $\begin{array}{l}2400 \cdot 0 \\
2250 \cdot 0 \\
3000 \cdot 0 \\
3500 \cdot 0 \\
3000 \cdot 0\end{array}$ & $\begin{array}{l}13 \cdot 0 \\
13 \cdot 0 \\
12 \cdot 0 \\
12 \cdot 0 \\
13 \cdot 0\end{array}$ \\
\hline
\end{tabular}

Table 6. Incorporation of $\left[I^{-14} C\right]$ acetate into kojic acid by resting Aspergillus flavus

$$
\begin{aligned}
& \text { Specific r.i.c. } \dagger \\
& \text { activity of kojic acid } \\
& \text { Substrate* } \quad \text { acid } / 5 \mathrm{ml} . \quad(\mathrm{m} \mu \mathrm{c} / \mu \text { mole }) \\
& {\left[\mathrm{I}-{ }^{14} \mathrm{C}\right] \text { Acetate } 7.5 \mu \mathrm{C}+\text { unlabelled acetate } 250} \\
& \begin{array}{l}
250 \mu \text { mole } \\
\left.{ }^{14} \mathrm{C}\right] \text { Acetate } 7.5 \mu \mathrm{C}+\text { unlabelled acetate } \mathrm{I} 25
\end{array} \\
& \mu \text { mole + unlabelled kojic acid I25 } \mu \text { mole } \\
& \begin{array}{lll}
2 \cdot I & 75 \cdot 3 & 2 \cdot 5 \\
2 \cdot 4 & 7 I \cdot 7 & 2 \cdot 4
\end{array}
\end{aligned}
$$

Data on formation of aflatoxin and kojic acid by Aspergillus flavus using labelled substrates are presented in Tables 6,7 and 8 . The specific activity and relative isotope content of the toxin were very high when labelled acetate was used as the substrate. With labelled kojic acid toxin formation was slight. Addition of unlabelled kojic acid to the medium containing labelled acetate as the substrate did not lower the specific 
activity or the relative isotope content of the synthesized toxin. Indeed there was a slight increase. Addition of unlabelled acetate to the medium with labelled kojic acid significantly reduced specific activity as well as the relative isotope content of the toxin synthesized. The results in Table 6 show that incorporation of the labelled carbon from [ $\left.{ }^{14} \mathrm{C}\right]$ acetate into kojic acid is not influenced by adding unlabelled kojic acid to the medium.

\begin{tabular}{|c|c|c|c|}
\hline Substrate* & $\begin{array}{c}\mu \text { mole of } \\
\text { affatoxin } / 5 \mathrm{ml} .\end{array}$ & $\begin{array}{c}\text { Specific } \\
\text { activity } \\
\text { in aflatoxin B } \\
\mathrm{m} \mu \mathrm{c} / \mu \text { mole }\end{array}$ & $\begin{array}{l}\text { r.i.c. } \dagger \text { of } \\
\text { aflatoxin }\end{array}$ \\
\hline $\begin{array}{l}{\left[\mathrm{I}-{ }^{14} \mathrm{C}\right] \text { Acetate } 7.5 \mu \mathrm{C}+\text { unlabelled acetate } 250} \\
\mu \text { mole } \\
{\left[\mathrm{I}-{ }^{14} \mathrm{C}\right] \text { Acetate } 7.5 \mu \mathrm{C}+\text { unlabelled acetate } \mathrm{I} 25}\end{array}$ & 0.64 & I $57^{\circ} 0$ & $5 \cdot 2$ \\
\hline$\mu$ mole + unlabelled kojic acid i $25 \mu$ mole & 0.64 & $204 \cdot 0$ & 6.8 \\
\hline
\end{tabular}

Table 8. Influence of acetate on the incorporation of ${ }^{14} \mathrm{C}$ from kojic acid into aflatoxin by resting Aspergillus flavus

\begin{tabular}{|c|c|c|}
\hline Substrate* & $\begin{array}{c}\mu \text { mole of } \\
\text { aflatoxin } / 5 \mathrm{ml} .\end{array}$ & $\begin{array}{c}\text { Specific } \\
\text { activity } \\
\text { in aflatoxin } \mathbf{B} \\
\mathrm{m} \mu \mathrm{c} / \mu \text { mole }\end{array}$ \\
\hline
\end{tabular}

$\left[{ }^{14} \mathrm{C}\right]$ Kojic acid $0.3 \mu \mathrm{C}+$ unlabelled kojic acid I $50 \mu$ mole
$\left.{ }^{14} \mathrm{C}\right] \mathrm{Kojic}$ acid $0.3 \mu \mathrm{C}+$ unlabelled acetate 250 $\mu$ mole

$$
0.3
$$

0.7

3.0

0.9
$\mathrm{I} \cdot 5$

$0 \cdot 75$

* I mg./ml. $\mathrm{NaHSO}_{3}$ added to the substrate for stimulation.

$\dagger$ Relative isotope content calculated as described by Adye \& Mateles (1964).

\section{DISCUSSION}

The data on the influence of substrates, $\mathrm{pH}$, temperature and surface area/volume ratio on toxin and kojic acid synthesis by Aspergillus flavus show that the syntheses of the two compounds follow two different pathways controlled by different enzyme systems and differently influenced by various chemical and physical factors. This conclusion is supported by the data on the influence of dithionite, malonate and nitrogen atmosphere on toxin and kojic acid formation. Even in those cases where kojic acid synthesis was high, there was no enhancement of toxin formation. This was true with the substrates alcohol and xylose and also at high incubation temperature. This shows the unsuitability of kojic acid as a substrate for aflatoxin synthesis and hence kojic acid does not seem to be an intermediate in aflatoxin synthesis. This conclusion is also supported by the data with ${ }^{14} \mathrm{C}$-compounds. The relative isotope content of the toxin is very high with labelled acetate as the substrate. If kojic acid formation were an intermediate step in toxin synthesis, unlabelled kojic acid added to the medium with labelled acetate should enter into the synthetic pathway and lower the specific activity 
or the relative isotope content of the toxin. The results show that unlabelled kojic acid had no such effect, even though as much as $90 \%$ of it was utilized by the organism. The data with $\left[{ }^{14} \mathrm{C}\right] \mathrm{kojic}$ acid further substantiate this view. Inclusion of unlabelled acetate with $\left[{ }^{14} \mathrm{C}\right]$ kojic acid markedly reduced the specific activity of the toxin but considerably enhanced aflatoxin formation thus showing that acetate, but not kojic acid was the preferred substrate for toxin synthesis. Since ${ }^{14} \mathrm{C}$ incorporation from acetate into kojic acid was quite high, this compound must be one of the normal metabolites of acetate metabolism and have no role in aflatoxin synthesis.

This investigation was supported by a grant-in-aid from PL-480 Funds, National Institutes of Health, U.S.A.

\section{REFERENCES}

ADYE, J. \& MATELES, R. I. (1964). Incorporation of labelled compounds into aflatoxins. Biochimica et Biophysica Acta 86, $4 \mathrm{r} 8$.

Basappa, S. C., Jayaraman, A., Sreenivasamurthy, V. \& Parpia, H. A. B. (r967). Effect of B-group vitamins and ethyl alcohol on aflatoxin production by Aspergillus oryzae. Indian Journal of Experimental Biology 5, 262.

Bentley, R. (1957). Preparation and analysis of kojic acid. Methods in Enzymology 3, 238.

DAvis, N. D. (1963). Growth and kojic acid production by Aspergillus flavus growing on peanut oil. Economic Botany 17, 263.

Heathcote, J. G., Child, J. J. \& Dutton, M. F. (1965). The possible role of kojic acid in the production of aflatoxin by Aspergillus flavus. Biochemical Journal 95, 23.

HOLKER, J. S. E. \& UNDERWOOD, J. G. (1964). A synthesis of cyclopentenocoumarin structurally related to aflatoxin $\mathrm{B}_{1}$. Chemistry and Industry, p. $\mathrm{I} 865$.

MayURA, K. \& SReEnIVASAmURTHY, V. (I969). Quantitative method of the estimation of aflatoxins in peanut and peanut products. Journal of Association of Official Agricultural Chemists 52, 69.

Parrish, F. W., Wiley, B. J., Simmons, E. G. \& Long, L. JUN. (I966). Production of aflatoxins and kojic acid by species of Aspergillus and penicillium. Applied Microbiology 14, I39. 